\title{
Marco Aurelio Rodríguez El árbol parlante Acerca del Silencio, la Palabra, la Imagen y la Nada
}

\author{
Calíope Ediciones
}

Santiago de Chile, 2008, 94 páginas.

Entre El árbol parlante y la última obra de Marco Rodríguez ha pasado un largo tiempo. Atrás quedó el tiempo en que Rodríguez escribía Nubes para rellenar paisajes que en verdad resulten, título de la aludida obra que data de 1996. Digo atrás no sólo porque entre obra y obra existe una distancia de doce años, sino más bien porque la distancia se hace evidente cuando se ha tenido la oportunidad de leerlas a ambas. Valga decir que, entre una y otra, hay una distancia tan abismante que puede resultar fácil pensar que están escritas por dos personas distintas. Y en cierto sentido es así. Con esta nueva obra, Rodríguez quiere dejar claro que el tiempo juega a su favor, que este árbol se ha tomado su tiempo para crecer, del mismo modo que el roble necesita del tiempo para mostrarse en toda su plenitud. Lo cierto es que nada se ha dejado ni ha quedado al azar. Este es un texto absolutamente intencionado, por esto verdaderamente logrado.

A mi modo de leer, el texto de Rodríguez tiene dos características que, unidas, trazan una cartografía textual del todo interesante. Por un lado, el conjunto de 29 'ejercicios literarios' tienen, tanto en el plano singular como en el colectivo, un hálito laberíntico. Con ello quiero simplemente consignar el hecho de que hay una imposibilidad intrínseca de reducirles a un tópico literario específico. En cada uno de ellos hay algo de lírica como de prosa; algo de ensayo como de filosofía; algo de fábula como de epistemología; con todo, algo que lo hace inclasificable. Pero también, y aquí la segunda característica, tiene un gesto lúdico. Lo lúdico tiene, en este orden de cosas, un sello eminentemente didáctico. Rodríguez, como buen pedagogo que es, intenta insinuarnos, por medio de esta "didáctica laberíntica" que ha trazado, que el camino que conduce hacia nosotros mismos, si bien no es fácil tampoco es imposible.

Para llevar a cabo esta tarea el autor ha propuesto y se ha propuesto a sí mismo una imagen más que interesante: el árbol. Desde siempre el árbol ha representado, en la mayoría de las culturas antiguas, un 
tópico (topos: lugar) de sabiduría. Sólo como ejemplo de lo que estamos hablando tráigase a la memoria el relato de los primeros capítulos del génesis, donde "El árbol de la vida y el árbol de la ciencia del bien y del mal"1 ocupan un lugar destacado en la geografía paradisíaca.

De seguro que este árbol que nos ofrece Rodríguez tiende a lo medular de lo que estamos diciendo. Esto es, ofrece, en cada una de sus hojas, algunas claves para entender al hombre en relación consigo mismo dentro del largo concierto de la historia colectiva.

Una historia del colectivo humano que ha transitado por luces y sombras, y con las cuales este árbol intenta hablar. Este árbol parlante tiene absolutamente claro el itinerario de este diálogo, puesto que, de modo muy sabio, sigue la misma secuencia de la historia de la humanidad. Se echa a hablar, como así lo indica el subtítulo, Acerca del silencio, la Palabra, la Imagen y la Nada.

En estas hojas no quedan ausentes los diálogos con la tradición poética griega, la interpelación a un Edipo, en clave de arquetipo freudiano, que intenta resolver el enigma de la esfinge que cada uno de nosotros parece llevar. Tampoco están ausentes los diálogos con un Dante o con un Borges y con todo lo que éstos no dejaron de asombrarse.

En resumen, este árbol parlante que es el mismo Marco Rodríguez despliega el itinerario de un viaje a lo profundo y complejo de la existencia humana. Por medio de esta cartografía textual, hace las veces de Odiseo navegante. Ofrece guiarnos a Ítaca, en un viaje lleno de riegos pero también plano de sentido. 